\title{
PERBEDAAN POLA MAKAN, AKTIVITAS FISIK DAN STATUS GIZI ANTARA MAHASISWA INDEKOS DAN TIDAK INDEKOS POLTEKKES KEMENKES RIAU
}

\author{
MUHARNI*, HASFOURNI MAIRYIANI, SEPTA RYANTI** \\ *Dosen Jurusan Gizi Poltekkes Kemenkes Riau \\ **Mahasiswa Jurusan Gizi Poltekkes Kemenkes Riau
}

\begin{abstract}
ABSTRAK
Penelitian ini bertujuan untuk mengetahui perbedaan pola makan, aktivitas fisik dan status gizi mahasiswa indekos dan tidak indekos Poltekkes Kemenkes Riau. Pola makan tersebut berdasarkan kepada frekuensi, jenis dan porsi makan mahasiswa indekos dan tidak indekos Poltekkes Kemenkes Riau. Jenis Penelitian ini menggunakan metode deskriptif analitik dengan desain cross sectional. Teknik pengambilan sampel adalah sampel 2 proporsi (two sided test) dengan responden sebanyak 92 orang, dengan mahasiswa yang indekos 46 orang dan mahasiswa tidak indekos 46 orang. Data yang dikumpulkan berupa data primer dan data sekunder meliputi data karakteristik responden, pola makan, aktivitas fisik mahasiswa dengan wawancara melalui kuesioner. Pengolahan data dilakukan dengan menggunakan uji independent sample t-test. Hasil penelitian menunjukkan bahwa ada perbedaan frekuensi makan mahasiswa indekos dan mahasiswa tidak indekos. Ada perbedaan jenis makanan mahasiswa indekos dan mahasisswa tidak indekos. Ada perbedaan porsi makan pokok, lauk-pauk, minyak dan gula mahasiswa indekos dan mahasiswa tidak indekos. Namun tidak ada perbedaan porsi makanan nabati, sayuran dan buah mahasiswa indekos dan mahasisswa tidak indekos. Tidak ada perbedaan aktivitas fisik antara mahasiswa indekos dan tidak indekos. Tidak ada perbedaan yang nyata status gizi mahasiswa indekos dan mahasiswa tidak indekos Poltekkes Kemenkes Riau.
\end{abstract}

Kata kunci : Pola makan, aktivitas fisik, status gizi.

\section{PENDAHULUAN}

Beberapa studi mengenai pola makan mahasiswa yang telah dilakukan oleh beberapa peneliti menunjukkan bahwa banyak mahasiswa yang memiliki pola makan yang tidak sesuai dengan pedoman umum gizi seimbang. Sebagian besar mahasiswa merupakan anak indekos yang tinggal jauh dari keluarga. Kebanyakan mereka memiliki kebiasaan mengkonsumsi makanan yang tidak sehat, kurang istirahat karena tidur larut malam dan kurang olahraga.

Setiap individu membutuhkan pola makan yang sehat dan seimbang untuk menjaga kesehatan dan untuk mendukung kelancaran aktifitas, terutama bagi individu yang memilki aktifitas keseharian yang padat misalnya pada mahasiswa. Mahasiswa tergolong dalam kelompok uisa transisi dari masa remaja akhir menjadi dewasa awal. Seseorang yang memasuki usia transisi ini sudah mulai peduli dan memperhatikan tentang asupan makan yang dikonsumsi untuk mencukupi kebutuhan nutrisinya, baik dari segi kebutuhan energi, vitamin, maupun mineral (Muharrom, 2006).

Banyak studi yang mempelajari tentang hubungan pola makan, aktivitas fisik dan status gizi. 
Namun belum banyak dilakukan penelitian tentang perbedaan pola makan, aktivitas fisik dan status gizi mahasiswa indekos dan tidak indekos. Berdasarkan data dan permasalahan diatas, maka peneliti tertarik untuk melakukan penelitian terhadap kelompok usia dewasa muda untuk melihat perbedaan konsumsi makan, aktivitas fisik dan status gizi pada mahasiswa indekos dan tidak indekos di Poltekkes Kemenkes Riau.

\section{METODE}

Jenis penelitian ini merupakan penelitian deskriptif analitik dengan metode penelitian adalah desain cross sectional. Penelitian dilakukan pada bulan Juni 2014 di Poltekkes Kemenkes Riau. Populasi yang digunakan adalah seluruh mahasiswa Poltekkes Kemenkes Riau dan sampel dalam penelitian ini adalah mahasiswa Poltekkes Kemenkes Riau yang memenuhi kriteria yaitu mahasiswa indekos (mahasiswa tidak tinggal dengan orang tua atau keluarganya), mahasiswa tidak indekos (mahasiswa yang tinggal bersama orang tuanya), mahasiswa yang tidak melaksanakan aktivitas diluar kampus (seperti dinas diluar kampus) dan bersedia menjadi responden. Jumlah mahasiswa yang memenuhi kriteria tersebut sebanyak 471 orang. Sampel dalam penelitian ini diambil dengan menggunakan metode 2 proporsi (two sided test). Data diperoleh melalui wawancara dengan menggunakan formulir Semi Quantitative Food Frequency Qumulatif (FFQ) dan HDDS (Household Dietray Diversity Score) untuk mengetahui pola makan responden, juga wawancara besarnya aktivitas fisik yang dilakukan seseorang dalam 24 jam dinyatakan dalam PAL (Physical Activity Level) atau tingkat aktivitas fisik. Data status gizi diperoleh dengan menggunakan indeks masa tubuh (IMT) yang diperoleh dari data antropometri dengan menimbang berat badan menggunakan timbangan injak digital dengan ketelitian 0,1 kg dan tinggi badan menggunakan microtoise dengan ketelitian 0,1 cm. Adapun uji statistik yang dilakukan adalah Uji Independent Sample $\mathrm{T}$ Test untuk menganalisis perbedaan pola makan, aktivitas fisik dan status gizi. Independen kedua kelompok sampel yang berbeda yang dibandingkan. Analisa data dilakukan dengan menggunakan program SPSS 17.00 for windows dengan tingkat kepercayaan $90 \%$.

\section{HASIL DAN PEMBAHASAN}

1. Karakteristik Mahasiswa

Karakteristik mahasiswa yang dikumpulkan dalam penelitian ini meliputi nama, jenis kelamin, umur, jurusan dan status tempat tinggal. Berdasarkan pengumpulan data primer melalui wawancara dengan kuesioner 92 menggambarkan bahwa dari 92 orang responden hanya 6 orang mahasiswa indekos dan tidak indekos yang berjenis kelamin laki - laki dan 86 orang perempuan. Berdasarkan data dari kemahasiswaan Poltekkes Riau, jumlah mahasiswa laki - laki (12 \%) lebih sedikit dibandingkan dengan mahasiswi perempuan (78 \%). Gambaran umur yang dijadikan responden pada penelitian ini dari umur 19-21 tahun jumlah dengan jumlah mahasiswa 92 orang. Ada minimal umur 19 dan maximal umur 21 tahun dengan median umur 20 tahun.

Karakteristik mahasiswa berdasarkan jurusan yang dijadikan responden pada penelitian ini dapat terlihat bahwa frekuensi tertinggi adalah jurusan gizi dengan jumlah 
persentase 43,5 \%. Sedangkan frekuensi pada jurusan keperawatan dan kebidanan sebanyak 25,8 \% dan 27,8 \%. Tingginya jumlah persentase jurusan gizi dikarenakan jurusan keperawatan dan kebidanan sedang menjalankan aktivitas diluar kampus seperti dinas.

2. Pola Makan

Pola makan pada variabel ini meliputi frekuensi makan, jenis makanan dan porsi makan.

Tabel 1. Distribusi Frekuensi Makan Mahasiswa Indekos Dan Tidak Indekos

\begin{tabular}{lllrlll}
\hline Frekuensi & \multicolumn{2}{l}{ Indekos } & \multicolumn{3}{l}{ Tidak } & \multirow{2}{*}{ P value } \\
& \multicolumn{4}{l}{ indekos } & \\
\cline { 2 - 5 } & $\mathrm{n}$ & $\%$ & $\mathrm{n}$ & $\%$ & \\
\hline Baik & 22 & 47,8 & 40 & 87 & \multirow{2}{*}{0,001} \\
Kurang & 24 & 52,2 & 6 & 13 & \\
\hline Total & 46 & 100 & 46 & 100 & \\
\hline
\end{tabular}

Dari Tabel 1 dapat diketahui bahwa persentase frekuensi makan mahasiswa yang memilki frekuensi makan yang baik lebih banyak pada mahasiswa tidak indekos $87 \%$ bila dibandingkan dengan mahasiswa indekos yang memiliki frekuensi makan yang baik yaitu 47,8 \%. Begitu juga dengan persentase mahasiswa yang memiliki frekuensi makan kurang lebih banyak pada mahasiswa indekos (52,2 \%) bila dibandingkan dengan mahasiswa tidak indekos yaitu $13 \%$.

Ada perbedaan yang signifikan frekuensi makan mahasiswa indekos dan tidak indekos dengan nilai $\mathrm{p}=$ 0,001. Frekuensi makan mahasiswa tidak indekos lebih baik dibandingkan dengan mahasiswa indekos. Hal ini disebabkan karena pada saat jam makan siang sebagian mahasiswa tidak indekos pulang kerumah untuk makan siang dan sebagian lagi tentu bagi lokasi rumahnya cukup jauh akan membawa bekal makanan untuk makan siang mereka. Kebanyakan para mahasiswa terutama yang tidak tinggal dengan orangtua atau merantau dari kota yang cukup jauh dari tempat kuliah kebanyakan makan yang tidak teratur, makan yang kurang dari 3 kali sehari tersebut yang menyebabkan energi yang masuk ke tubuh tidak seimbang atau kekurangan kalori yang menyebabkan kurangnya gizi empat sehat lima sempurna pada kalangan mahasiswa (Nugroho, 2013).

Tabel 2. Distribusi Jenis Makanan Mahasiswa Indekos Dan Tidak Indekos

\begin{tabular}{cccccc}
\hline \multirow{2}{*}{$\begin{array}{c}\text { Jenis } \\
\text { makanan }\end{array}$} & \multicolumn{2}{c}{ Indekos } & \multicolumn{2}{c}{ Tidak indekos } & \multirow{2}{p}{} \\
\cline { 2 - 4 } & $\mathrm{n}$ & $\%$ & $\mathrm{n}$ & $\%$ & value \\
\hline Rendah & 4 & 8,7 & 1 & 2,2 & \\
Medium & 20 & 43,5 & 9 & 19,6 & 0,003 \\
Tinggi & 22 & 47,8 & 36 & 78,3 & \\
\hline Total & 46 & 100 & 46 & 100 & \\
\hline
\end{tabular}

Dari Tabel 2 dapat diketahui bahwa persentase jenis makanan mahasiswa yang memiliki jenis makanan rendah lebih banyak pada mahasiswa indekos (8,7 \%) bila dibandingkan dengan mahasiswa tidak indekos yaitu 2,2 \%. Begitu juga dengan persentase mahasiswa dengan jenis makanan yang medium lebih banyak pada mahasiswa indekos dibandingkan dengan mahasiswa tidak indekos yaitu 19,6 \%. Dan persentase mahasiswa dengan jenis makanan tinggi lebih banyak pada mahasiswa tidak indekos (78,3 \%) dibandingkan dengan mahasiswa indekos yaitu 47,8 $\%$.

Ada perbedaan yang signifikan jenis makanan mahasiswa indekos dan tidak indekos dengan nilai $\mathrm{p}=0,003$. Perbedaan jenis makanan mahasiswa indekos dan tidak indekos ini terlihat dari jumlah jenis makanan rendah lebih banyak pada mahasiswa indekos 
dibandingkan tidak indekos. Karena berdasarkan hasil recall persentase jenis makanan yang rendah $<3$ kelompok makanan yaitu kelompok nasi, ikan dan minyak. Hal ini disebabkan karena mahasiswa indekos tidak memperhatikan makanan yang dimakan apabila telah melakukan aktifitas kampus.

Tabel 3. Distribusi Porsi Makan Mahasiswa Indekos Dan Tidak Indekos

\begin{tabular}{|c|c|c|c|c|c|c|}
\hline \multicolumn{2}{|c|}{ Porsi makanan } & \multicolumn{2}{|c|}{ Indekos } & \multicolumn{2}{|c|}{$\begin{array}{r}\text { Tidak } \\
\text { indekos }\end{array}$} & \multirow[b]{2}{*}{ value } \\
\hline & & $\mathrm{n}$ & $\%$ & $\mathrm{n}$ & \multirow{2}{*}{$\begin{array}{l}\% \\
55,3\end{array}$} & \\
\hline \multirow{2}{*}{$\begin{array}{l}\text { Makanan } \\
\text { pokok }\end{array}$} & Baik & 11 & 24,4 & 26 & & \multirow{2}{*}{0,001} \\
\hline & Buruk & 34 & 75,6 & 21 & 44,7 & \\
\hline \multicolumn{2}{|c|}{ Total } & 46 & 100 & 46 & 100 & \\
\hline \multirow{2}{*}{$\begin{array}{l}\text { Makanan } \\
\text { lauk pauk }\end{array}$} & Baik & 19 & 41,3 & 26 & 55,3 & \multirow{2}{*}{0,00} \\
\hline & Buruk & 25 & 58,7 & 21 & 44,7 & \\
\hline \multicolumn{2}{|c|}{ Total } & 46 & 100 & 46 & 100 & \\
\hline \multirow{2}{*}{$\begin{array}{c}\text { Makanan } \\
\text { nabati }\end{array}$} & Baik & 12 & 12,2 & 30 & 63,8 & \multirow{2}{*}{0,07} \\
\hline & Buruk & 33 & 87,8 & 17 & 36,2 & \\
\hline \multicolumn{2}{|c|}{ Total } & 46 & 100 & 46 & 100 & \\
\hline \multirow[t]{2}{*}{ Sayuran } & Baik & 13 & 28,9 & 24 & 51,1 & \multirow[b]{2}{*}{0,02} \\
\hline & Buruk & 32 & 711 & 23 & 489 & \\
\hline \multicolumn{2}{|c|}{ Total } & 46 & 100 & 46 & 100 & \\
\hline \multirow[t]{3}{*}{ Buah } & Baik & 12 & 26,7 & 14 & 29,8 & \multirow{3}{*}{0,64} \\
\hline & & & & & & \\
\hline & Buruk & 34 & 73,3 & 32 & 70,2 & \\
\hline \multicolumn{2}{|c|}{ Total } & 46 & 100 & 46 & 100 & \\
\hline \multirow[t]{3}{*}{ Minyak } & Baik & 16 & 35,6 & 36 & 76,6 & \multirow{3}{*}{0,00} \\
\hline & & & & & & \\
\hline & Buruk & 29 & 64,4 & 11 & 23,4 & \\
\hline \multicolumn{2}{|c|}{ Total } & 46 & 100 & 46 & 100 & \\
\hline \multirow[t]{2}{*}{ Gula } & Baik & 26 & 57,8 & 38 & 76,6 & \multirow[b]{2}{*}{0,00} \\
\hline & Buruk & 19 & 42,2 & 8 & 23,4 & \\
\hline \multicolumn{2}{|c|}{ Total } & 46 & 100 & 46 & 100 & \\
\hline
\end{tabular}

Dari Tabel 3 dapat diketahui bahwa porsi makanan pokok, lauk pauk, nabati, sayuran, minyak, buah dan gula yang baik lebih banyak pada mahasiswa tidak indekos dibandingkan dengan porsi makanan pokok mahasiswa indekos yaitu. Hal ini dapat dilihat dari persentase pada tabel.

\section{Aktifitas Fisik}

Sebagian besar orang menghabiskan waktu sadar mereka dalam bentuk aktivitas duduk, berdiri dan berjalan. Tidak terkecuali mahasiswa yang kebanyakan waktunya digunakan untuk belajar dan beraktivitas di kampus.

Tabel 4. Distribusi Responden Berdasarkan Aktivitas Fisik Mahasiswa Indekos dan Tidak Indekos

\begin{tabular}{cccccc}
\hline $\begin{array}{c}\text { Aktivitas } \\
\text { fisik }\end{array}$ & Indekos & $\begin{array}{c}\text { Tidak } \\
\text { Indekos }\end{array}$ & $\begin{array}{c}\text { p- } \\
\text { value }\end{array}$ \\
\cline { 2 - 5 } & $\mathbf{n}$ & $\mathbf{\%}$ & $\mathbf{n}$ & $\mathbf{\%}$ & \\
\hline Ringan & 20 & 21.7 & 20 & 21.7 & \\
Sedang & 21 & 22.8 & 21 & 22.8 & 0.215 \\
Berat & 5 & 5.4 & 5 & 5.4 & \\
\hline Total & 46 & 100 & 46 & 100 & \\
\hline
\end{tabular}

Tabel 4 menggambarkan tingkat aktivitas mahasiswa indekos dan tidak indekos terbesar yaitu aktivitas sedang sebanyak 21 orang (22.8\%), dan mahasiswa dengan aktivitas berat $5.4 \%$. Aktivitas berat yang dilakukan mahasiswa dilihat dari nilai PAR yaitu menonton, bermain tenis, bermain sepak bola, mengendarai motor, menyapu lantai atau menonton, tidur, berpakaian yang dilakukan dalam waktu yang lama sehingga dikategorikan aktifitas berat.

Dari hasil uji statistik menunjukkan tidak ada perbedaan aktivitas fisik antara mahasiswa indekos dan tidak indekos, karena aktivitas fisik mahasiswa indekos dan tidak indekos sama-sama dalam kategori sedang dan ringan. Contoh aktivitas yang sering dilakukan mereka yaitu, menaiki tangga, mencuci piring, memasak dan 
menyetrika, duduk sambil makan, menulis, dan berbicara.

Poltekkes Kemenkes Riau adalah jenjang pendidikan tinggi vokasional yang menghasilkan sumber daya manusia di bidang kesehatan. Jam perkuliahan yang cukup padat dan hampir sama antar jurusan membuat mahasiswa kurang melakukan aktivitas di luar. Hal inilah yang menjadi faktor aktivitas mahasiswa berada dalam kategori sedang baik mahasiswa indekos maupun tidak indekos.

Aktivitas fisik merupakan bentuk dari perilaku manusia, meliputi semau gerak tubuh mulai dari gerakan kecil hingga turut serta dalam lari meraton. Orang yang aktif memang membutuhkan makanan yang lebih banyak untuk menghasilkan energi. Maka untuk meningkatkan energi orang yang aktif tidak hanya dapat mengandalkan makanan yang tinggi kalori, tetapi kaya akan zat gizi (Gibney, 2009).

\section{Status Gizi}

Status gizi adalah ekspresi dari keadaan keseimbangan dalam bentuk tertentu atau perwujudan dari keadaan gizi dalam bentuk variabel tertentu (Supariasa, 2012). Salah satu cara yang dapat digunakan untuk menilai status gizi adalah pengukuran antropometri. Pada dewasa status gizi dapat diukur dengan menggunakan Indeks Massa Tubuh (IMT) (Almatsier, 2004). Distribusi status gizi mahasiswa indekos dan mahasiswa tidak indekos Poltekkes Kemenkes Riau dapat dilihat pada Tabel 5:
Tabel 5. Distribusi Status Gizi Mahasiswa Indekos dan Mahasiswa Tidak Indekos

\begin{tabular}{cccccc}
\hline $\begin{array}{c}\text { Status } \\
\text { Gizi }\end{array}$ & \multicolumn{2}{c}{ Indekos } & \multicolumn{2}{c}{$\begin{array}{c}\text { Tidak } \\
\text { Indekos }\end{array}$} & $\begin{array}{c}\text { p- } \\
\text { value }\end{array}$ \\
\cline { 2 - 5 } & $\mathbf{n}$ & $\mathbf{\%}$ & $\mathbf{n}$ & $\mathbf{\%}$ & \\
\hline Normal & 40 & 87 & 39 & 84.8 & \\
Kurus & 6 & 13 & 7 & 15.2 & 0.158 \\
\hline Total & 46 & 100 & 46 & 100 & \\
\hline
\end{tabular}

Berdasarkan Tabel 5 diketahui

bahwa persentase mahasiswa yang memiliki status gizi normal pada mahasiswa indekos $87 \%$ dan mahasiswa tidak indekos yang memiliki status gizi normal yaitu 84.8\%. Persentase mahasiswa yang memiliki status gizi kurus yang tidak indekos $15.2 \%$ dan mahasiswa indekos yaitu $13 \%$.

Berdasarkan uji statistik menunjukkan tidak ada perbedaan yang nyata antara status gizi mahasiswa indekos dan mahasiswa tidak indekos. Sebagian besar status gizi mahasiswa indekos maupun tidak indekos termasuk dalam kategori normal. Hal ini disebabkan karena pola makan dan aktivitas mereka hampir sama.

Menurut Almatsier (2004) status gizi baik atau status gizi optimal terjadi bila tubuh memperoleh cukup zat-zat gizi yang digunakan secara efisien, sehingga memungkinkan pertumbuhan fisik, otak, kemampuan kerja dan kesehatan secara umum pada tingkat setinggi mungkin. Masalah gizi, baik kekurangan maupun kelebihan gizi dapat terjadi pada semua kelompok usia. Salah satu cara untuk mengetahui seseorang kekurangan atau kelebihan gizi adalah melalui penilaian antropometri. Standar antropometri untuk menilai status gizi orang dewasa adalah Indeks Massa Tubuh (IMT). 


\section{KESIMPULAN}

Berdasarkan penelitian ini dapat disimpulkan bahwa ada perbedaan frekuensi makan, jenis makanan dan porsi makan pokok, lauk-pauk, minyak dan gula antara mahasiswa indekos dan tidak indekos di Poltekkes Kemenkes Riau. Tidak ada perbedaan asupan energi, karbohidrat dan lemak antara mahasiswa indekos dan tidak indekos Poltekkes Kemenkes Riau. Namun ada perbedaan pada asupan protein. Kemudian tidak ada perbedaan aktivitas fisik dan juga status gizi antara mahasiswa indekos dan tidak indekos Poltekkes Kemenkes Riau.

\section{DAFTAR PUSTAKA}

Almatsier, S. (2001). Prinsip Dasar Ilmu Gizi. Jakarta, Indonesia : PT GramediaPustaka Utama

Almatsier, S. (2006). Prinsip Dasar Ilmu Gizi. Jakarta, Indonesia : PT GramediaPustaka Utama

Anonim. (2010). Pengertian Makan. Diakses dari http://id.wikipedia.org/wiki/Ma kan

Anonim. (2014). Bagaimana Fungsi Karbohidrat Sederhana Kompleks Bagi Tubuh. Diakses dari http://www.sridianti.com/

Arisman. (2007). Prinsip Dasar Ilmu Gizi. Jakarta, Indonesia : PT Gramedia Pustaka Utama

Aritonang, E. (2003). Hubungan Konsumsi Pangan Dengan Gizi Lebih Pada Anak TK Dikotamadya Medan Tahun 2003(Lembaga Penelitian Universitas Sumatera Utara, Medan Indonesia).

Ayu, S. (2012). Perbedaan Asupan energi, protein dan status gizi pada remaja panti asuhan dan pondok pesantren studi kasus di panti asuhan darul khadlonah dan pondok pesantren baitul muqodas pekalongan tahun 2012 (Karya tulis ilmiah, Diploma Program Pendidikan Sarjana Kedokteran Fakultas Kedokteran Universitas Diponegoro, Semarang, Indonesia).

Baliawati,Y.F et al. (2004). Pengantar Pangan Dan Gizi. Jakarta, Indonesia: Penebar Swadaya

Brown, J.E. et al. (2005). Nutrition Thhrough Life Circle. South Melbourne, Vic., Australia Thomson Wadsworth

Departemen Gizi dan Kesehatan Masyarakat. (2007). Gizi Dan Kesehatan Masyarakat. Jakarta, Indonesia :PT Raja Grafindo persada.

Depkes RI. (2009). Pola Makan. Jakarta, Indonesia : Ditjen Pembinaan Masyarakat. Direktorat Bina Gizi Masyarakat.

FAO. (2006). Guidelines For Measuring Household and Individual Dietary Diversity [Food and Agriculture Organization].

Farida, I. (2007). Faktor-Faktor Yang Berhubungan Dengan Perilaku Konsumsi Buah Dan Sayur Pada Remaja (Skrispsi Sarjana, Syarif Hidayatullah UIN Jakarta, Indonesia).

Fitri, R. (2013). Deskripsi Pola Makan Penderita Maag Pada Mahasiswa Jurusan Kesejahteraan Keluarga Fakultas Teknik Universitas Negeri Padang (Skripsi Sarjana, Universitas Negeri Padang, Sumatera Barat, Indonesia).

Ginting, H, Naomi. (2002). Hubungan Pengetahuan Gizi Dengan 
Pola Makan Pada Mahasiswa Kesehatan Dan Non Kesehatan Yang Kost Di Kelurahan Padang Bulan Medan (Skripsi Sarjana, FKM USU Medan, Indonesia).

Harna. (2009). Pola Makan Sehat bab I pdf. Diakses dari www.damandari.or.id/file/ratna suhartiniunair

Indrawagita, L. (2009). Hubungan Status Gizi, Aktifitas Fisik Dan Asupan Gizi Dengan Kebugaran Mahasiswi Program Studi FKMUI (Skripsi Sarjana FKM Universitas Indonesia Jakarta, Indonesia).

Hartono, A. (2006). Terapan Gizi dan Diet. Jakarta, Indonesia : EGC

Kembaren, T. (2004). Faktor-Faktor Yang Berhubungan Dengan Pola Makan Mahasiswa (Skripsi Sarjana, Institut Pertanian Bogor, Indonesia). Diakses pada Desember 2012.

Kementrian Kesehatan RI. (2010). Standar Antropometri Penilaian Status Gizi Anak. Jakarta, Indonesia

Kurdanto. (2006). Aktivitas Konsumsi Energi Dan Protein Serta Status Gizi Nutrisi (Skripsi Sarjana, Politeknik Kesehatan Yogyakarta, Indonesia): Diakses pada Desember 2012.

Muharrom. (2006). Kajian Tingkat Asupan Zat Gizi Mahasiswa Yang Berdomisili Di Asrama Universitas Andalas (Skripsi Sarjana, Universitas Andalas Padang, Indonesia. Diakses pada Desember 2012.

Notoatmodjo, S. (2007). Promosi Kesehatan dan Ilmu Perilaku. Jakarta, Indonesia : Rineka Cipta
Nugroho, S. (2013). Globalisasi dan Pola Makan Mahasiswa (Skripsi Sarjana UNIKA Atmajaya Jakarta, Indonesia)

Okviani. (2011). Frekuensi Makan. Diakses dari http://blogspot.com/2012/05/p engertian-frekuensimakan.html.

Paath, Rumdasih \& Heryati. (2005). Zat Gizi Untuk Diet. Jakarta, Indonesia: Bumi Aksara.

Poltekkes Kemenkes Riau. (2013). Profil Poltekkes Kemenkes Riau Tahun 2013. Pekanbaru Riau, Indonesia.

PGS. (2014). Pedoman Gizi Seimbang. Jakarta, Indonesia : Direktur Jenderal Bina Gizi dan KIA

Puji,S. (2010). Faktor - Faktor Yang Berhubungan Dengan Pola Makan Mahasiswa Kesehatan Masyarakat Fakultas Kedokteran Dan Ilmu Kesehatan Universitas Negeri Syarif Hidayatullah Jakarta Tahun 2011 (Skripsi Sarjana Fakultas Kedokteran dan Ilmu Kesehatan Universitas Islam Negeri Syarif Hidayatullah Jakarta, Indonesia). Diakses pada Desember 2012.

Rahmawati, A. (2006). Motivasi Berprestasi Mahasiswa Ditinjau Dari Pola Asuh (Skripsi Sarjana, FKUSU Medan, Indonesia).

Riset Kesehatan Dasar (Riskesdas). (2013). Pedoman Pewawancara Petugas Pengumpul Data. Jakarta, Indonesia : Badan Litbangkes, Depkes RI

Ruwaidah, Amin. (2007). Penyakit Akibat Lalai Mengkonsumsi Buah dan Sayur serta Solusi 
Penyembuhannya. Diakses pada 15 April 2010 dari www.healindonesia.com/2009/0 $5 / 15 /$

Santoso, S dan Ranti, L. A. (2004). Kesehatan Dan Gizi. Jakarta, Indonesia: Rineka Cipta

Simanjuntak, David. (1998). Hubungan Tingkat Pengetahuan Gizi, Kebiasaan Makan dan Faktor Ekonomi dengan Status Gizi Mahasiswa USU yang Indekost Di sekitar kampus USU(Skripsi Sarjana, USU Medan, Indonesia).

Supariasa IPN, Bakri B, Fajar I. (2001). Penilaian Status Gizi. Jakarta, Indonesia : Penerbit Buku Kedokteran EGC

WKNPG. (2012). Widyakarya Nasional Pangan dan Gizi. Jakarta, Indonesia :

Lembaga Ilmu Pengetahuan Indonesia. 